\title{
Knowledge Sharing and Transfer in an Open Innovation Context: Mapping Scientific Evolution
}

\author{
Izaskun Alvarez-Meaza ${ }^{1, * \mathbb{C}}$, Naiara Pikatza-Gorrotxategi ${ }^{1}$ and Rosa Maria Rio-Belver ${ }^{2} \mathbb{D}$ \\ 1 Technology, Foresight and Management (TFM) Group, Department of Industrial Organization and \\ Management Engineering, Faculty of Engineering, University of the Basque Country, Pl. Ingeniero Torres \\ Quevedo, 48013 Bilbao, Spain; naiara.picaza@ehu.eus \\ 2 Technology, Foresight and Management (TFM) Group, Department of Industrial Organization and \\ Management Engineering, Faculty of Engineering, University of the Basque Country, C/Nieves Cano 12, \\ 01006 Vitoria, Spain; rosamaria.rio@ehu.eus \\ * Correspondence: izaskun.alvarez@ehu.eus; Tel.: +34-946-014-245
}

Received: 26 November 2020; Accepted: 9 December 2020; Published: 10 December 2020

\begin{abstract}
The essence of innovation lies in knowledge, which is why open innovation opens the door to knowledge transfer with agents outside the organization. In order to comprehend the joint scientific trajectory of these two areas of knowledge, the aim of this study is to identify and analyze the main indicators of scientific behavior involved in the research field related to the link between open innovation and knowledge transfer or knowledge sharing concepts through bibliometric and network analysis. The results show clear European leadership in scientific production developed in universities. In addition, the high quality of the main sources of diffusion infers publications of good scientific quality. The most recognized source of knowledge used in new research is directed towards university-company relationships in an open innovation environment. Network analysis related to keywords has allowed us to define the most interesting, relevant fields of research, highlighting the importance acquired by topics such as 'communication', 'inter-organizational context' and 'education', to better focus on future research of the scientific community. It can be concluded that the scientific development of both concepts is an active field in the academic community, and also, that new key terms appear, opening new paths of research.
\end{abstract}

Keywords: open innovation; knowledge transfer; knowledge sharing; bibliometric analysis; network analysis

\section{Introduction}

In the last decades, we have passed through a closed innovation model to an open one. This means that companies have gradually reversed their ways of investing in their research toward a collaborative method [1]. In a closed innovation model, companies used to invest in their own R\&D department and so not only were they able to keep new ideas under control but also all their knowledge, tacit and explicit. However, now this closed, static model has become highly difficult to manage; resources are constantly flowing, moving, changing and increasing in complexity. As employees start changing from one company to another, so does information, making it very difficult for the firm to contain ideas $[2,3]$. In this dynamic context, the open innovation (OI) paradigm appears, replacing the previous closed innovation paradigm, and it represents a new approach into the innovation management shift from a closed to an open model [4]. The OI model is used to indicate how organizations work together with innovation praxis, particularly the relevance of input and output flows of knowledge in the innovation process or for developing new products [5]. We can understand OI as the use of intentional incomes and outcomes of knowledge to further a firm's innovation and to extend markets to innovate externally. 
The definition perceives organizations as able to use information and procedures from inside and outside the firm, and this is the way it has to be if they wish to progress technologically [6].

Innovation is critical for enterprises, and employee innovation is needed as a basic unit of innovation; this can be promoted by knowledge sharing [7-10]. According to Ritala et al. [11], sharing and obtaining knowledge commonly induces innovation. However, obtaining knowledge is not an easy procedure, and transferring knowledge among organizations is an implicit part of this procedure [5]. The ability to transform knowledge through sharing will lead to one level of innovation or another [12]. Moreover, according to Pian et al. [10], organization-oriented knowledge sharing impacts innovative behavior more than individual-oriented knowledge sharing. In addition to the complexity of knowledge sharing and transfer within organizations, this is evolving towards a sharing of knowledge between organizations, such as university-business relations [13,14]. It is necessary to have an effective knowledge management system that facilitates the absorption of knowledge arising from knowledge sharing within and among organizations [15].

The importance of research profiling opens the doors to bibliometric techniques. Based on a significant amount of academic literature, the bibliometric method makes quantitative analysis of information [16] possible. Bibliometric analysis allows the identification of research priorities, new applications, geographic location of development and research networks, among others [17,18]. Therefore, it becomes a fundamental tool in the science-related decision-making process, and its results can be considered an important aid to facilitate the allocation of funding by the relevant agencies [19]. In addition, network analysis makes it possible to visualize the constantly evolving dynamic connections that occur in science [20-22]. This technique will allow the identification and quantification of collaboration patterns among authors, organizations and countries, also known as Social Network Analysis [23], as well as to pinpoint and group the main research topics [24]. In addition, the basic measurements of graph theory, such as degree centrality, betweenness centrality and closeness centrality will allow us to quantify the behavior of the network, identifying the main relationships between countries, organizations and authors, and identifying the research topics hubs that enable prediction of future research trends $[25,26]$.

Organizational environments based on an OI perspective open the doors to knowledge transfer and sharing; and vice versa, the importance of knowledge flow for the innovation process stimulates commitment to a strategic organizational approach based on OI. This link is reinforced by the results of the bibliometric analyses carried out by Randhawa et al. [27] and Gao et al. [28] that present knowledge as an important research topic within science that analyzes the OI paradigm.

Within the scientific environment linked to OI, several authors have opted for different bibliometric techniques to study the OI concept from different approaches, such as Kovàcs et al. [29], Randhawa et al. [27], de Paulo et al. [30], Ebrahim and Bong [31], Lopes and de Carvalho [32], Le et al. [33], Aziz et al. [34] and Gao et al. [28]. However, these techniques have also been used to analyze the OI environment from other perspectives, such as small and medium-sized enterprises by Odriozola-Fernández et al. [35], large firms by Noviaristanti [36], absorptive capacity by Segui-Mas et al. [37], sustainable tourism by Della Corte et al. [38] and its relationship with solar energy technologies by Paulo and Porto [23]. Regarding the research carried out in the field of knowledge transfer or sharing using bibliometric techniques, Naushad Ali et al. [39] present a bibliometric analysis about knowledge sharing in general from 1990 to 2016, offering an overview of trending publications, journals, countries and organizations. Considering that technology transfer and entrepreneurship are related to knowledge transfer, Skute et al. [40] depicts the bibliometric analysis to conduct an interpretation based on the clustering of the main terms. Concerning knowledge management, a bibliometric mapping overview has been conducted by Kokol et al. [41], identifying the research trends. In addition, the study by Aman [42] measures the knowledge transfer related to scientist mobility. With regard to absorptive capacity, Apriliyanti and Alon [43] have conducted a bibliometric analysis and, as a result, knowledge transfer is among the main research streams in absorptive capacity. As for the development of bibliometric studies of OI from a knowledge transfer perspective, they have 
not been identified. The closest approximation is presented by the work carried out by Agostini et al. [44] in which bibliometric techniques are used to study the evolution of scientific literature in knowledge management within an inter-organizational context, which is similar but not equal to the term OI.

A review of the scientific literature linked to the OI paradigm has identified the flow of knowledge as a fundamental cornerstone on which this new organizational approach is based, as well as various research works based on scientific literature reviews through bibliometric methods that ratify the field of knowledge as a relevant topic, among others. OI is complex, moreover, it is a dynamic process influenced by strategies incorporating dynamic elements that reflect the current technological world, making it difficult to investigate [32,45]. Therefore, it is more practical to limit the OI paradigm to its knowledge flow approach. Consequently, this study contributes to filling the literary gap in the analysis of scientific research related to the relationship between the OI paradigm and the process of knowledge transfer.

To offer an overview for future research, this article aims to investigate the relation between OI and knowledge transfer or knowledge sharing concepts from a scientific perspective. The research conducts a bibliometric analysis to identify and analyze the key indicators related to scientific context and a network analysis to identify the strongest major relationships between main actors and a conceptual framework and prediction of future research tendencies. The combination of both allows us to achieve the aim of the article: identifying the evolution of the field, the main producers and their cooperation patterns, the main sources of dissemination, the conceptual framework, as well as the main sources of knowledge. This may help the scientific community and its scientific environment in the approach and design of new research paths, the allocation of scientific funding to areas of interest in future scenarios and, in turn, the search for new collaborative groups, which will open up new paths for both national and international collaboration.

\section{Methods}

Various methods or techniques can be used to review the scientific literature [46]. In this case, a bibliometric and network analysis is chosen to achieve the objective of the work: to analyze the OI paradigm from a knowledge transfer or knowledge sharing perspective. These techniques are of value to assess the current state, identify strategic relationships and predict development trends [28,35]. To this end, the proposed methodology consists of three phases described below (see Figure 1). These phases will make it possible to identify and quantify, on the one hand, academic performance (trends, authors, countries, organizations...) along with the main research subareas and, on the other hand, the main collaboration networks and the conceptual framework of topics, thus satisfying the established objective. However, the aim of this research practice is that it can be applied to any type of emerging field of scientific research.

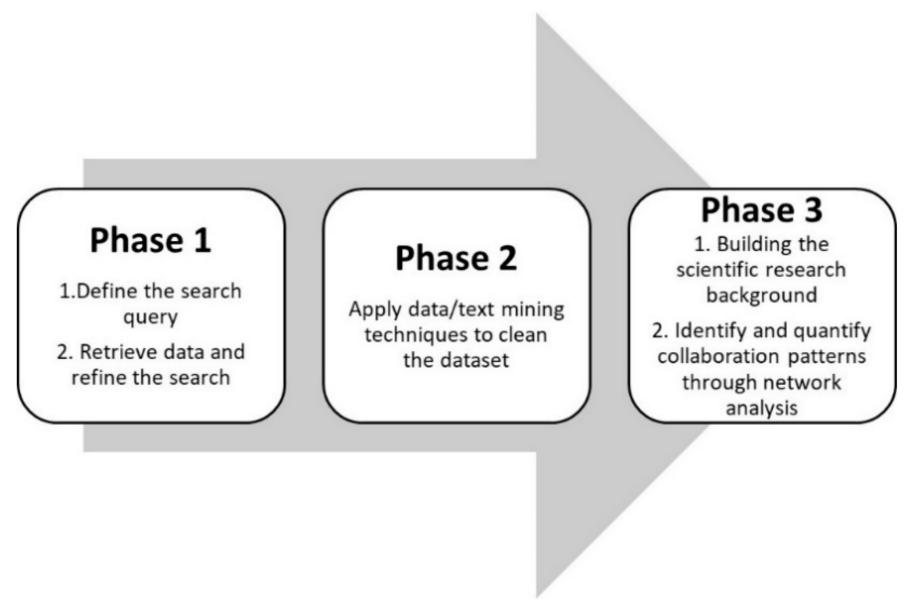

Figure 1. Phases of the research work. 
In order to build the scientific profile of the research area, the following three phases are carried out. In the first phase, the search query is defined, making it possible to obtain the dataset formed by scientific publications related to the emerging research field being analyzed. In the case of knowledge sharing or transfer in OI, the specific database is generated from the Core Collection of Web of Science (WoS) scientific database. WoS Core Collection database is chosen for two reasons; the first is that the rest of WoS accessible databases contain hardly any publications in the field of study, and the second reason is that the Core Collection provides higher quality data, since it contains all information and cited references of the publications, which allows more extensive analysis [32]. WoS has been from the three most important scientific databases (Scopus, WoS and Google Scholar (GS)) because it is the one that produces more results. However, as presented by different studies [47-49] the best results would be obtained by using all three databases. Nevertheless, in this case, the three databases complement each other and the WoS database presents the most complete search result. Since burgeoning research fields cover different approaches, the definition of the query is an essential process, since a query with a wide recall makes the search less precise. Therefore, a balance has to be established between call and precision, which usually have an inverse relationship [50,51]. Although bibliometric studies related to OI have used different terms as synonyms for OI in their queries $[28,30]$, in this research we have chosen to limit the study to the term defined by Chesbrough [52] in order to focus the study on the OI paradigm as established in the objective. Therefore, the query was built using "open innovation" and "knowledge transfer" or "knowledge sharing" as author keywords (47 documents), obtaining a highly precise query, but not enough to conduct a bibliometric analysis. In addition, to accomplish greater recall, the search for the same terms based on title-abstract-keywords (TS) is added to the query (see Table 1). In order to analyze all the articles that cover the field of research, the search period has not been limited. As the first document is from 2007, the time span of the dataset was established between 2007 and actually (November 2020). The final dataset is composed by a total of 272 articles, conference proceedings, books and book series for the defined time span.

Table 1. Search query for Knowledge sharing/transfer in OI adapted to WoS database.

\begin{tabular}{c} 
Search Query \\
\hline $\mathrm{TS}=\left(\right.$ ("open innovation" $\left.{ }^{*}\right)$ AND TS $=($ "knowledge sharing" OR “knowledge transfer" $)$ \\
\hline
\end{tabular}

In the second phase, the dataset obtained in phase 1 is cleaned up using data and text mining tools. The scientific dataset was imported into Vantage PointR (VP) software [53], text mining software that allows us to classify the raw data, and clean the data of specific fields (authors, author's keywords, ... ) by using fuzzy matching techniques in order to group words that have the same meaning. Once these two steps are completed, a combination of statistical operations will allow us to show and quantify the results based on the dataset of scientific publications.

In the last and third phase, the profile of the scientific literature described in the results is built, identifying the trend of publications and their citations, the main producers and their location, the main sources of dissemination, the main research subareas and their evolution and the most cited publications that represent the main sources of knowledge. In addition, the study is completed through a network analysis, making it possible to identify and analyze the patterns of collaboration between countries, organizations and authors, and the conceptual network based on research topics. To do this, starting from co-occurrence matrices created in the VP software, the networks are generated and visualized through Gephi software [54].

\section{Results}

\subsection{Research Trends: Publications and Citations}

The progress of publications and citations is represented in Figure 2. Since 2010, the number of publications has remained constant, with an average of 21 articles per year; the year 2016 prominent for 
having 41 publications. It is true that the first publication identified is from the year 2007, having only five records, and the topic loses interest in the next two years, but in 2010 it is again of interest to the scientific community. However, the number of citations per year rapidly augmented from 2010, and by 2020 (751) this was over twelve times higher than in 2012 (62). Hence, the science research community is focusing its attention on concepts related to the approach of knowledge management in the OI model.

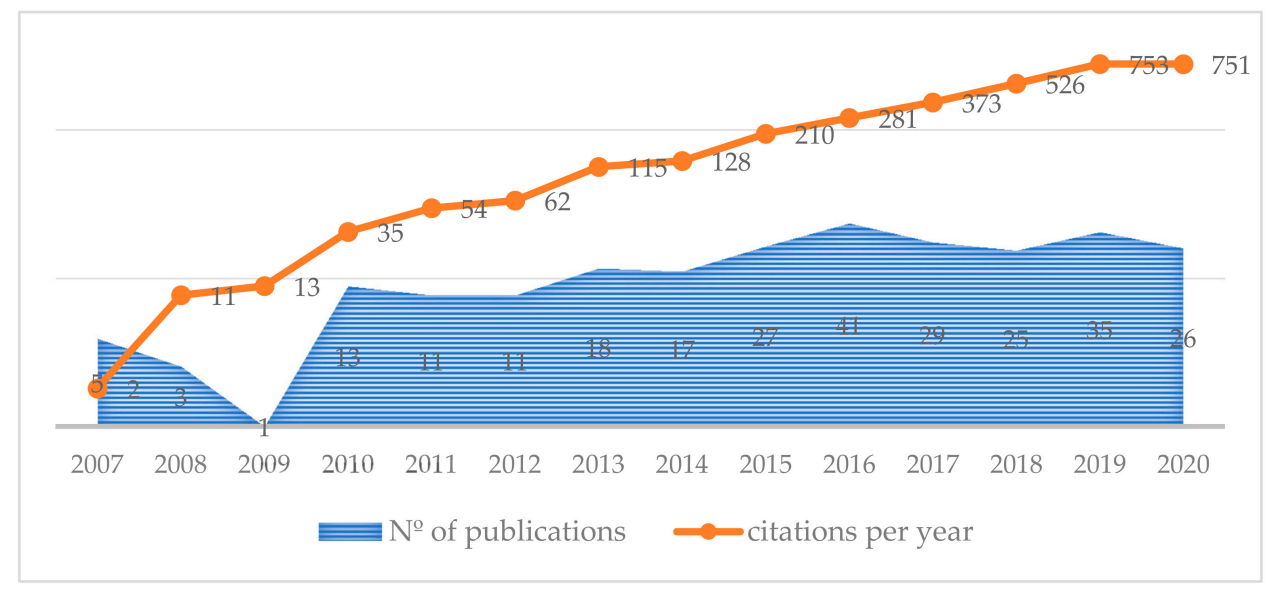

Figure 2. Number of publications and citations from 2007 to 2020.

\subsection{Main Producers in Research}

One of the purposes of a bibliometric analysis is to ascertain the geographical location of scientific development, which allows the generation of an indicator that measures the excellence and the concentration of scientific research carried out by both countries and organizations. The most prolific countries in terms of knowledge sharing/transfer in OI publishing (see Figure 3) are mainly geographically concentrated in Europe but are also located in China and USA. The countries with the highest number of publications are from Europe: UK (52), Italy (46) and Germany (26), representing almost half of the publications. In general, Europe is the main driving force behind this area of research.

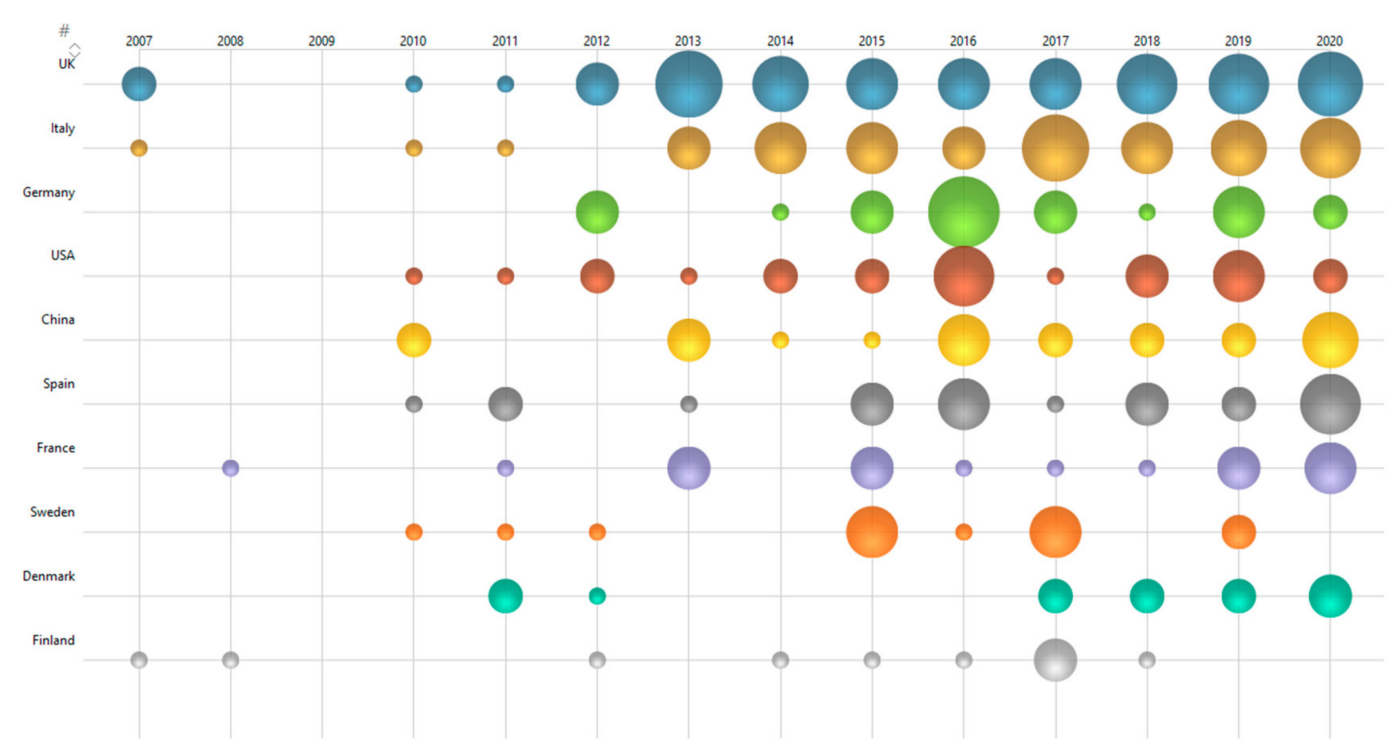

Figure 3. Evolution of number of publications by country according to publication year, from 2007 to 2020 . 
In addition, the UK, Italy and Finland are highlighted as pioneers in scientific research (with regards to the 2007 start date). With the exception of Finland, they have developed steady scientific production, and they have grown progressively over time. Production in China and the USA, despite being the fourth and fifth countries with most publications, began to be relevant in 2010 but without constant growth in recent years.

A network analysis has made it possible to identify and quantify the collaborative activities between the different countries. Gephi software has modeled the co-occurrence network created in VP, mapping the countries that have at least one collaboration (see Figure 4). In addition, the node size represents the weighted degree, which indicates the number of connections (edges) that a node has with other nodes, but weighted by the thickness of each edge. Consequently, the country most active in academic collaborations in the research field is the UK. In the cluster led by the UK, mainly European countries are collaborating, including Russia and New Zealand. The second cluster is led by France, Spain and Belgium, with collaborations grouped with Argentina, Lebanon, Canada and Algeria (Asia and America). As far as the USA-related cluster is concerned, collaboration is mainly with Germany, Netherlands, Switzerland and Portugal. China, as the main node, forms another cluster, mainly with Asian countries, such as South Korea, Singapore and Pakistan.

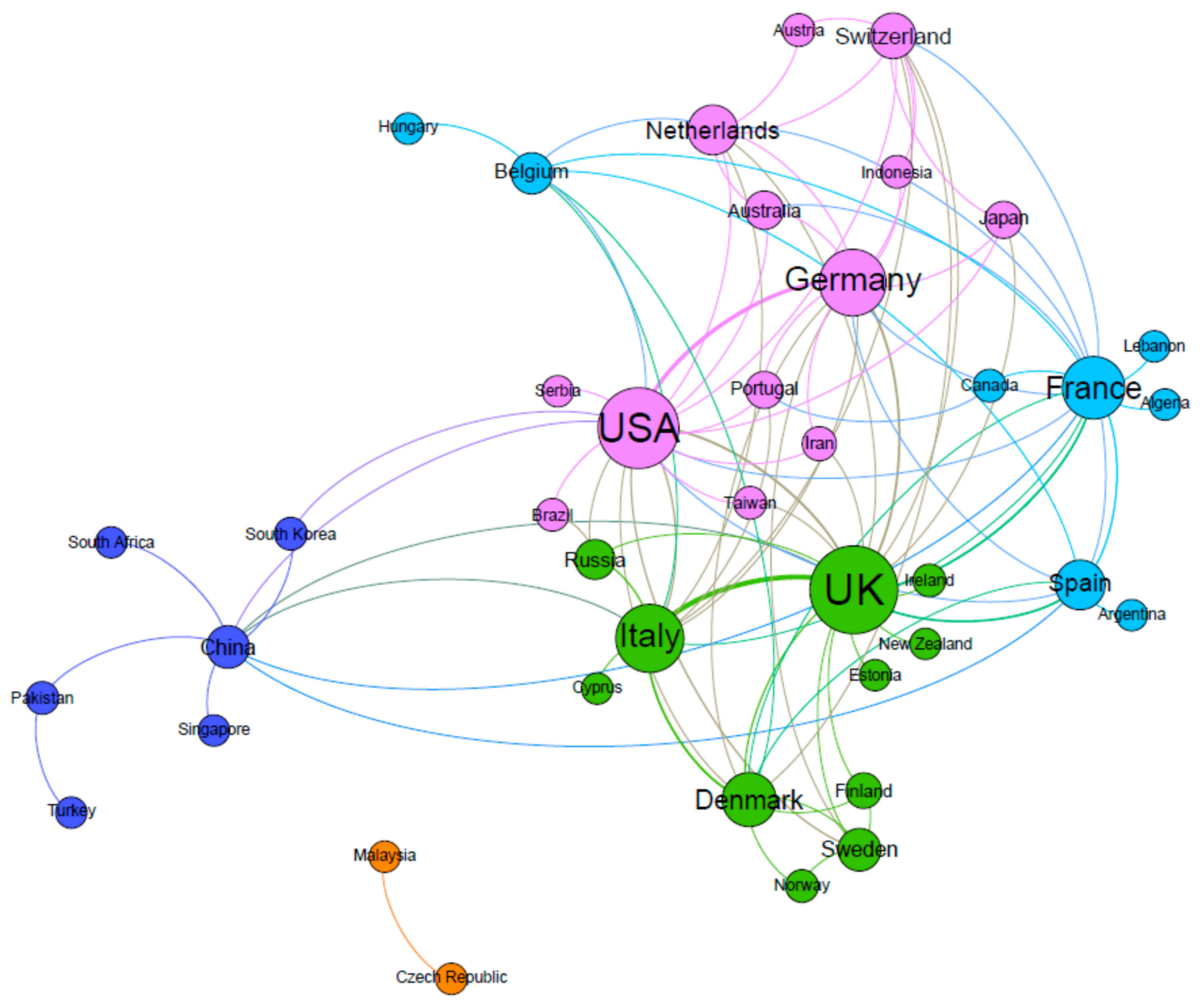

Figure 4. Research collaboration among countries.

The size of the node represents the level of collaboration, and in order to quantify and analyze the countries' cooperation pattern, Table 2 shows the ranking of the most productive and collaborative countries, intermediary countries and influential countries. The United Kingdom remains in first place as the most productive and collaborative, however, countries such as France, the United States, Sweden, Belgium and China improve their ranking in terms of collaboration, unlike Germany and Finland. 
In general, the collaboration patterns are very similar in science, with the leading countries being in the central positions, followed by emerging countries, whose affinity is possibly defined by language, colonial links and proximate economies, among others [55,56]. In this case, Switzerland develops little, however, the little it does develop is done cooperatively, whereas China, considered a science powerhouse, collaborates less than it produces. Another interesting fact that the network provides is the betweenness centrality field, i.e., the role of intermediary that the country plays. In this case, the USA, UK, China and France are the countries that most help countries without direct contact to collaborate. In addition, the countries with the greatest influence on others are quantified in the network through the closeness centrality indicator. The results indicate that USA, UK, France and Italy are the most influential, and China drops in the ranking, even though it continues to be among the ten most influential. In general, European countries are the most influential over other countries.

Regarding organizations, Table 3 describes the 10 most productive organizations, including the number of documents, their affiliated countries, and their average citations per publication. The most productive organization is University of Exeter (UK) with eight publications, but there is hardly any difference in the number of publications in the top 10. In the scientific development of the research topic (272 publications), 388 organizations form part of it, which means that scientific production is widely distributed and not very concentrated in just a few nodes. If we analyze average citations per publication in order to analyze the impact on the scientific context, University of Exeter, Queens University of Belfast, University of Turin and University of London, besides being the most productive (all of them very similar), are also the ones that transfer more knowledge to the scientific community (they have the highest average). However, University of Naples Federico II, Scuola Super Sant Anna and Ramon Llull University- ESADE have low average of citations to guarantee that these publications become sources of knowledge for other research works.

The network analysis will allow us to determine, among other characteristics of the network, the degree of collaboration between organizations. The results obtained show a network with a high level of modularity (0.935), which indicates that there are dense connections between the nodes of the same module but few connections with other nodes of other modules, resulting in the formation of many clusters (see Figure 5).

Table 4 shows the results of the network analysis, identifying the most collaborative organizations (Weighted Degree), and at the same time, those that play an important role as intermediaries of other organizations that have no direct connection (Betweenness Centrality) and their influence (Closeness Centrality). Except for the University St. Gallen (Switzerland) (2 publications), the results indicate that the most productive countries are the ones that collaborate the most. However, if we analyze the organizations that play an important role as intermediaries for other organizations that do not have direct contact with each other, the results change. Figure 5 shows where the main intermediary organizations are located in the network. Copenhagen Business School (three publications) is the one with the highest betweenness centrality, providing the most help for contact between non-linked organizations, but a medium-low influence on other organizations, according to its value of closeness centrality (0.3838). The University of Turin, besides being a productive and collaborative organization, plays an important role as an intermediary, with influence on other universities. The University of Adelaide, despite being very collaborative, does not play a significant role as an intermediary, suggesting that everything it has developed has been done with the same research group (as far as organizations are concerned). The University of Birmingham and the University of Naples Parthenope, although not very productive, do play an important role as intermediaries. 


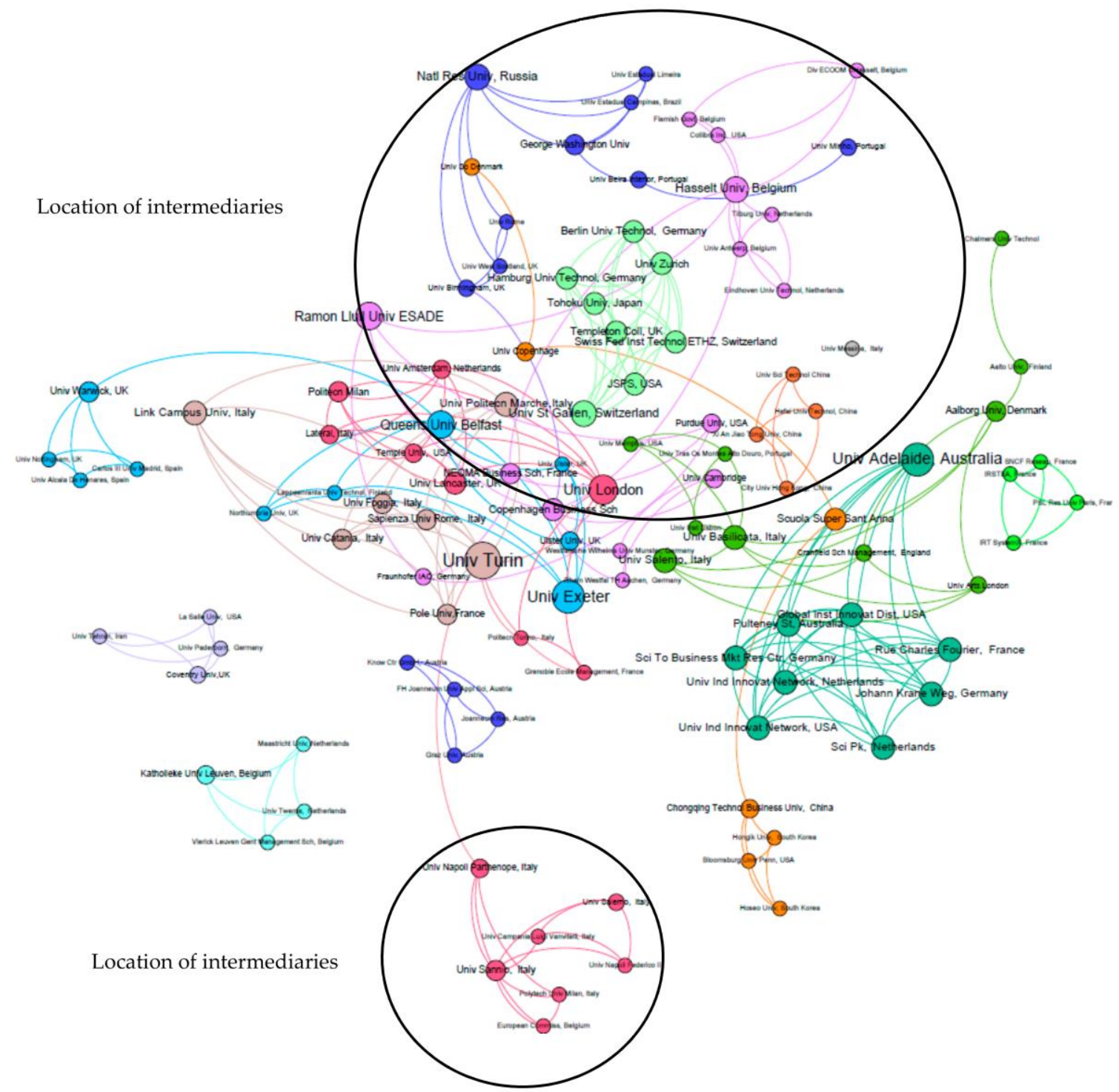

Figure 5. Research collaboration among organizations. 
Table 2. Ranking of the most productive, collaborative, intermediary and influential countries.

\begin{tabular}{|c|c|c|c|c|c|c|c|c|}
\hline Ranked & $\begin{array}{c}\text { Countries Most } \\
\text { Productive }\end{array}$ & $\begin{array}{c}\text { Number of } \\
\text { Publications }\end{array}$ & $\begin{array}{l}\text { Countries Most } \\
\text { Collaborative }\end{array}$ & $\begin{array}{c}\text { Weighted } \\
\text { Degree }\end{array}$ & $\begin{array}{c}\text { Intermediary } \\
\text { Countries }\end{array}$ & $\begin{array}{c}\text { Betweenness } \\
\text { Centrality }\end{array}$ & $\begin{array}{c}\text { Influential } \\
\text { Countries }\end{array}$ & $\begin{array}{l}\text { Closeness } \\
\text { Centrality }\end{array}$ \\
\hline 1 & UK & 52 & UK & 21 & USA & 171.47 & USA & 0.6727 \\
\hline 2 & Italy & 46 & USA & 14 & UK & 169.88 & UK & 0.6379 \\
\hline 3 & Germany & 26 & Italy & 13 & China & 143.65 & France & 0.6065 \\
\hline 4 & USA & 25 & Germany & 9 & France & 119.33 & Italy & 0.5781 \\
\hline 5 & China & 23 & France & 8 & Italy & 62.88 & Germany & 0.5606 \\
\hline 6 & Spain & 23 & Denmark & 7 & Spain & 47.35 & Spain & 0.5441 \\
\hline 7 & France & 18 & Netherlands & 7 & Germany & 45.42 & Denmark & 0.5441 \\
\hline 8 & Sweden & 14 & Spain & 6 & Denmark & 41.63 & China & 0.5362 \\
\hline 9 & Denmark & 12 & Switzerland & 6 & Belgium & 37.4 & Switzerland & 0.5211 \\
\hline 10 & Finland & 10 & China & 5 & Pakistan & 36 & Netherlands & 0.5138 \\
\hline
\end{tabular}


Table 3. The main producers: organizations.

\begin{tabular}{cccc}
\hline Organization & Publications & Country & Average Citations per Publication \\
\hline University of Exeter & 8 & UK & 20.88 \\
Queens University of Belfast & 5 & UK & 21.40 \\
University of Turin & 5 & Italy & 35.4 \\
Polytechnic University of Timisoara & 5 & Romania & 4.80 \\
Ramon Llull University-ESADE & 5 & Spain & 2 \\
Scuola Super Sant Anna & 5 & Italy & 2.20 \\
University of London & 5 & UK & 23 \\
University of Napoli Federico II & 5 & Italy & 0 \\
University of Oradea & 5 & Romania & 4.80 \\
Chalmers University of Technology & 4 & Sweden & 6.25 \\
\hline
\end{tabular}

Table 4. Ranking of the most collaborative and intermediary organizations.

\begin{tabular}{|c|c|c|c|c|c|}
\hline Ranked & $\begin{array}{l}\text { Organizations Most } \\
\text { Collaborative }\end{array}$ & $\begin{array}{l}\text { Weighted } \\
\text { Degree }\end{array}$ & $\begin{array}{l}\text { Intermediary } \\
\text { Organizations }\end{array}$ & $\begin{array}{l}\text { Betweenness } \\
\text { Centrality }\end{array}$ & $\begin{array}{l}\text { Closeness } \\
\text { Centrality }\end{array}$ \\
\hline 1 & Univ Turin (5) & 15.0 & $\begin{array}{c}\text { Copenhagen Business } \\
\text { Sch (3) }\end{array}$ & 437.0 & 0.3838 \\
\hline 2 & Univ Exeter (8) & 13.0 & Univ Turin (5) & 387.5 & 0.5230 \\
\hline 3 & $\begin{array}{l}\text { Univ Adelaide, } \\
\text { Australia (4) }\end{array}$ & 13.0 & $\begin{array}{l}\text { Univ Birmingham, } \\
\text { UK (2) }\end{array}$ & 345.0 & 0.3584 \\
\hline 4 & Univ London (5) & 11.0 & $\begin{array}{l}\text { National Research } \\
\text { Univ, Russia (4) }\end{array}$ & 332.0 & 0.3247 \\
\hline 5 & $\begin{array}{l}\text { Queens Univ } \\
\text { Belfast (5) }\end{array}$ & 10.0 & Univ London (5) & 293.0 & 0.4722 \\
\hline 6 & $\begin{array}{l}\text { Ramon Llull Univ } \\
\text { ESADE (5) }\end{array}$ & 10.0 & $\begin{array}{l}\text { George Washington } \\
\text { Univ (3) }\end{array}$ & 217.0 & 0.2753 \\
\hline 7 & $\begin{array}{l}\text { National Research } \\
\text { Univ, Russia (4) }\end{array}$ & 9.0 & $\begin{array}{l}\text { Hasselt Univ, } \\
\text { Belgium (3) }\end{array}$ & 201.0 & 0.3333 \\
\hline 8 & $\begin{array}{l}\text { Hasselt Univ } \\
\text { Belgium (3) }\end{array}$ & 9 & $\begin{array}{c}\text { Univ Napoli } \\
\text { Parthenope, Italy (2) }\end{array}$ & 189.0 & 0.4096 \\
\hline 9 & $\begin{array}{l}\text { Univ St Gallen, } \\
\text { Switzerland (2) }\end{array}$ & 9 & $\begin{array}{l}\text { Ramon Llull Univ } \\
\text { ESADE (5) }\end{array}$ & 179.5 & 0.3392 \\
\hline 10 & $\begin{array}{l}\text { Univ Salento, } \\
\text { Italy (4) }\end{array}$ & 8 & $\begin{array}{l}\text { Univ Beira Interior, } \\
\text { Portugal (3) }\end{array}$ & 169.0 & 0.2317 \\
\hline
\end{tabular}

() number of publications.

The analysis of the most productive authors (see Table 5) reveals Allen T. Alexander (University of Exeter Business School, UK) as the most published researcher in the field. The other nine top authors have between three and five publications, however, if we evaluate their citation average per publication, Marcel Bogers differs from the rest of the top authors by having the highest average citations per publication (30.33). Only the authors Allen T Alexander (20.88) and Kristel Miller (19) follow, which indicates that their research work is transcendent for other investigations. In general, the top authors publish their research mainly in research areas related to Business Economics, Engineering, Operation Research Management Science and Information Science Library Science, based on the categorization stipulated by Web of Science [57], which has a total of 252 subject categories in science, social sciences, arts and humanities. 
Table 5. The main producers: authors.

\begin{tabular}{ccccc}
\hline Authors & Organization & Country & Counts & $\begin{array}{c}\text { Average Citations } \\
\text { per Publication }\end{array}$ \\
\hline Alexander, Allen T & University of Exeter & UK & 8 & 20.88 \\
Miller, Kristel & Qusiness School & UK & 5 & 19 \\
Baban, Calin Florin & University of Oradea & Romania & 5 & 4.80 \\
Draghici, Anca & $\begin{array}{c}\text { Polytechnic University } \\
\text { of Timisoara }\end{array}$ & Romania & 5 & 4.80 \\
Di Minin, Alberto & Scuola Super Sant Anna & Italy & 4 & 1.5 \\
Rumanti, Augustina Asih & Institute Technology of Bandung & Indonesia & 4 & 1 \\
Wiratmadja, Iwan & Institute Technology of Bandung & Indonesia & 4 & 1 \\
Inrawan & University of Copenhagen & Denmark & 3 & 30.33 \\
Bogers, Marcel & University of Naples Federico II & Italy & 3 & 0 \\
Bonacci, Isabella & Polytechnic University & Romania & 3 & 7.67 \\
Ivascu, Larisa Victoria & of Timisoara & & &
\end{tabular}

a The organization with which they publish the documents.

An interesting method to gauge scientific collaboration is the analysis of co-authorship networks. Based on the matrix of authors' co-occurrences, the layout of the network is generated and mapped using Gephi software. Figure 6 shows the most collaborative research groups. The network has a high modularity (0.988) which indicates that many clusters are formed and, in this case, there is no collaboration between the different research groups (each group forms a cluster). The most collaborative authors according to the calculation of their weighted degree are Alexander, A.T. (17), Miller, K. (16) and Di Minin, A. (15) and the research groups formed by Draghici and Baban (15 and 13) and Rumanti and Wiratmadja (12). It should be noted that Di Minin, A. is the author who has the strongest role as an intermediary (betweenness centrality: 62.33), and Ramos Castro, J. who, despite having only two publications, is a collaborative author and intermediary over other actors.
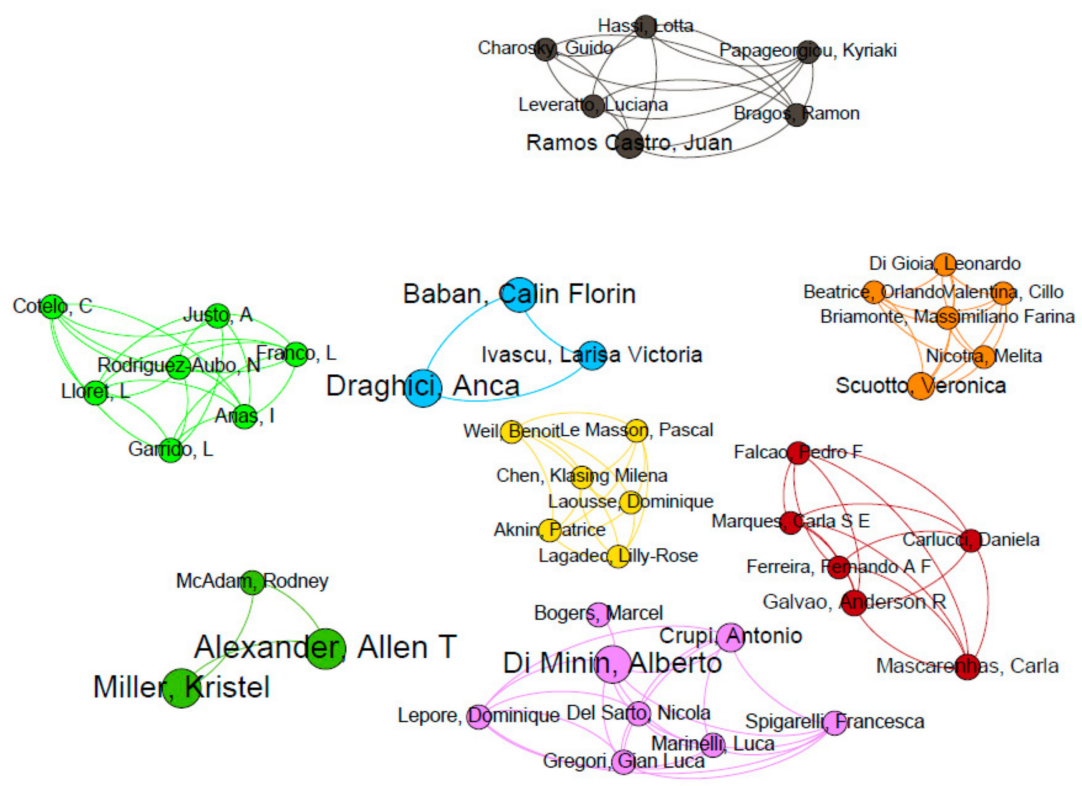

Rumanti, Augustina Asih

Wiratmadja IVyan Inrawan

Figure 6. Co-authorship network. 


\subsection{Sources of Diffusion}

Analyzing the sources of diffusion of publications makes it possible to identify the journals most related to the subject important for the producer (authors), and at the same time, allow the publishers to determine relevant information to guide their positioning strategy. The search has been done in Journals, Conference proceedings and Books, with $66 \%$ of publications published in Journals and $30 \%$ in Conference Proceedings. According to Journals, the most important sources of diffusion are linked to areas of innovation and management. The 272 documents were published in 170 different sources; therefore, there are many sources of diffusion. The main journals are 'Journal of Knowledge Management', 'Technology Forecasting and Social Change', 'R\&D Management', 'International Journal of Innovation Management' and 'Technovation', all having more than six articles (15.5\%) (see Figure 7).

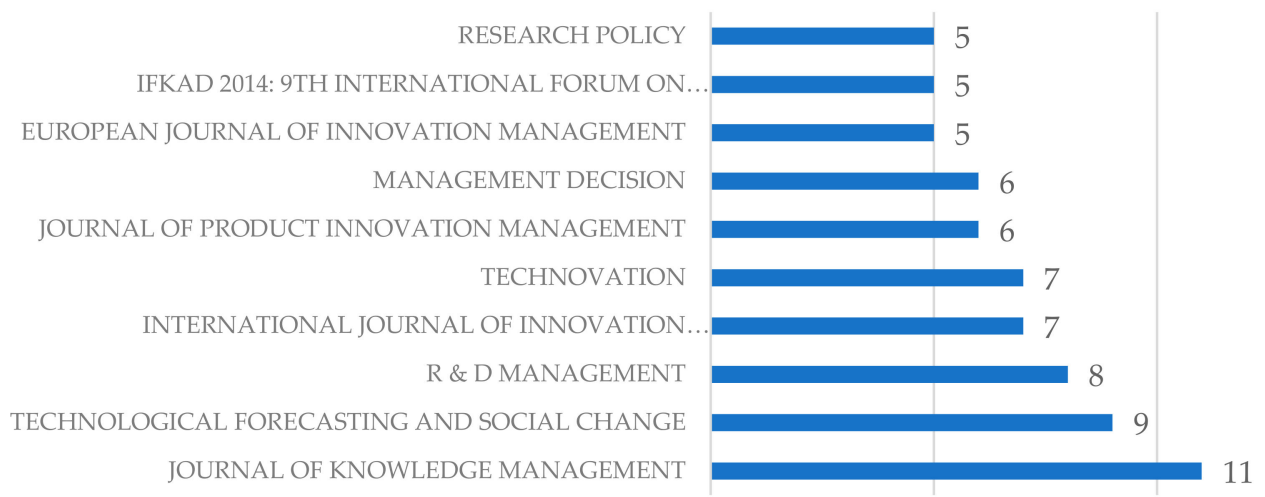

Figure 7. The top sources of diffusion.

Among the top 10 sources is the conference 'IFKAD 2014: 9th International Forum on Knowledge Asset Dynamics: Knowledge and Management Models for Sustainable Growth' with five publications. If we analyze the quality of the sources, both the Journal Citation Report (JCR) and the Scimago Journal Rank (SJR) indexing, the sources with the highest number of documents are located in high quartiles. Table 6 presents a description of the quality of the five sources with the greatest number of documents according to the JCR and SJR indicators, and the average number of citations of the articles of the study published in them. Except for the International Journal of Innovation Management that is indexed in a high quartile according to the SJR index, all sources are indexed in the upper quartile according to JCR and SJR, 'Management' being the field of research common to all of them. It should be noted that the articles published in the journals with the highest quality (quartile 1) are those with the most average citations; therefore, their research becomes a source of knowledge for other research. It also denotes quality in the research carried out. However, the IFKAD2014 Conference publications have not been cited or been the basis of other research work.

\subsection{Research Topics}

Author keywords analysis provides an insight into research trends, helping to identify areas of interest to the scientific community related to knowledge sharing or transfer in an open innovation context. Using VP software, 655 author keywords were obtained from 272 publications. In addition, the analysis of the first year in which a keyword in an obtained dataset appears allows the maturity level of the research field to be measured. In this case, as shown in Figure 8, there are two phases in its scientific evolution. On the one hand, the initial development phase is identified between the years 2007-2009, during which hardly any new knowledge terms are generated. On the other hand, between 2010 and 2019 new terms are generated above the scientific production, producing a science growth phase. The year 2020 has not been considered in this analysis because it may not be truly representative or objective as the year has not ended. 
Table 6. Main sources of publications (with more than six publications).

\begin{tabular}{|c|c|c|c|c|c|c|c|c|c|}
\hline \multirow[b]{2}{*}{ Sources } & \multirow{2}{*}{$\begin{array}{l}\text { Type of } \\
\text { Source }\end{array}$} & \multirow{2}{*}{$\begin{array}{l}\text { Average of } \\
\text { Citations per } \\
\text { Publications }\end{array}$} & \multicolumn{3}{|c|}{ JCR } & \multicolumn{3}{|c|}{ SJR } & \multirow[b]{2}{*}{ Publisher } \\
\hline & & & Field of Research & Quartile & $\begin{array}{c}\text { Impact } \\
\text { Factor } 2019\end{array}$ & Field of Research & Quartile & $\begin{array}{c}\text { Impact } \\
\text { Factor } 2019\end{array}$ & \\
\hline $\begin{array}{c}\text { Journal of } \\
\text { Knowledge } \\
\text { Management }\end{array}$ & Journal & 18.27 & $\begin{array}{l}\text { Information Science } \\
\text { \& Library } \\
\text { Science/Management }\end{array}$ & Q1 & 4.745 & $\begin{array}{l}\text { Management Technology } \\
\text { and Innovation/Strategy } \\
\text { and Management }\end{array}$ & Q1 & 1.75 & Emerald \\
\hline $\begin{array}{l}\text { Technological } \\
\text { Forecasting and } \\
\text { Social Change }\end{array}$ & Journal & 20.56 & $\begin{array}{l}\text { Business/Regional } \\
\text { \&Urban Planning }\end{array}$ & Q1 & 5.846 & $\begin{array}{c}\text { and Innovation/Business } \\
\text { and International } \\
\text { Management/Applied } \\
\text { Psychology }\end{array}$ & Q1 & 1.82 & Elsevier \\
\hline $\begin{array}{c}\text { R\&D } \\
\text { Management }\end{array}$ & Journal & 26.13 & Business/Management & Q2 & 2.908 & $\begin{array}{c}\text { Business and International } \\
\text { Management/Management } \\
\text { of Technology and } \\
\text { Innovation/Strategy and } \\
\text { Management }\end{array}$ & Q1 & 1.25 & Wiley \\
\hline $\begin{array}{l}\text { International } \\
\text { Journal of } \\
\text { Innovation } \\
\text { Management }\end{array}$ & Journal & 5.86 & & & & $\begin{array}{c}\text { Business and International } \\
\text { Management }\end{array}$ & Q2 & 0.49 & $\begin{array}{c}\text { World } \\
\text { Scientific } \\
\text { Publishing }\end{array}$ \\
\hline Technovation & Journal & 46.43 & $\begin{array}{c}\text { Industrial Engineering/ } \\
\text { Management/Operation } \\
\text { Research and } \\
\text { Management Science }\end{array}$ & Q1 & 5.729 & $\begin{array}{l}\text { Engineering/Management of } \\
\text { Technology and Innovation }\end{array}$ & Q1 & 2.8 & Elsevier \\
\hline
\end{tabular}




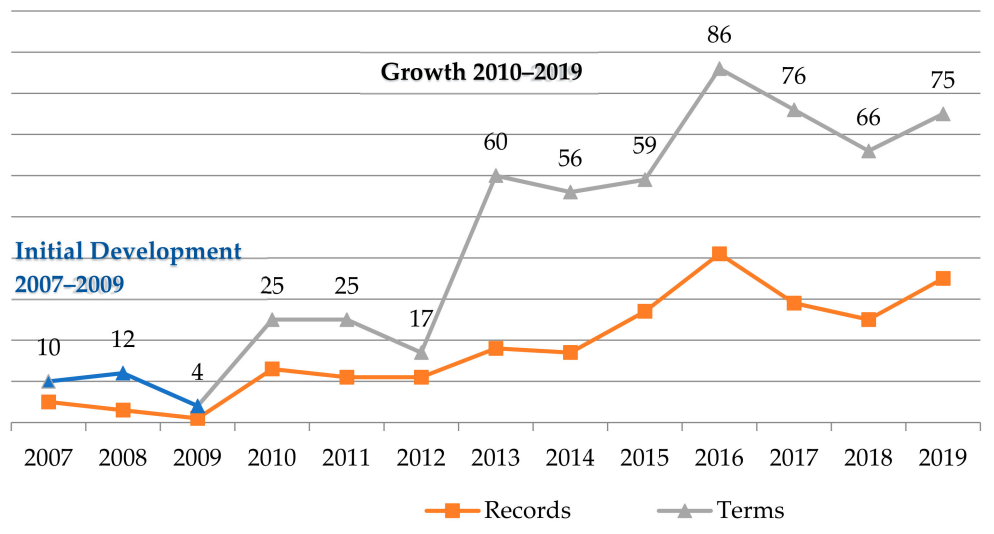

Figure 8. Number of new author keywords any year vs. the number of records for that year.

The network of author keywords, based on a matrix of co-occurrences and generated by Gephi, makes it possible to monitor the relational structure of the main research topics for the period 2007-2020, revealing areas of research interest. In order to reduce any possible disparity in research focus produced by single-used keywords and to make it readable, the network of author keywords (see Figure 9) presents terms with a high number of connections $(>10)$. The network has an average modularity $(0.503)$ which indicates that the terms are grouped in many clusters (32) but there are 9 robust clusters that group from 22 to 171 elements, as is the cluster led by 'Open Innovation', which include themes related to SMEs, University-Industry collaboration, Knowledge transfer, Technology transfer, Innovation, network, crowdsourcing, collaborative innovation, technology innovation, innovation ecosystems and healthcare. 'Knowledge sharing' as topic leader of the second biggest cluster (92 elements) relates to co-creation, R\&D cooperation, new product development, automobile industry, innovation management and social media. And the third cluster with more terms (62) is led by 'Absorptive Capability' and linked to process innovation, dynamic capabilities, inbound Open Innovation, external knowledge open innovation practices and social networks.

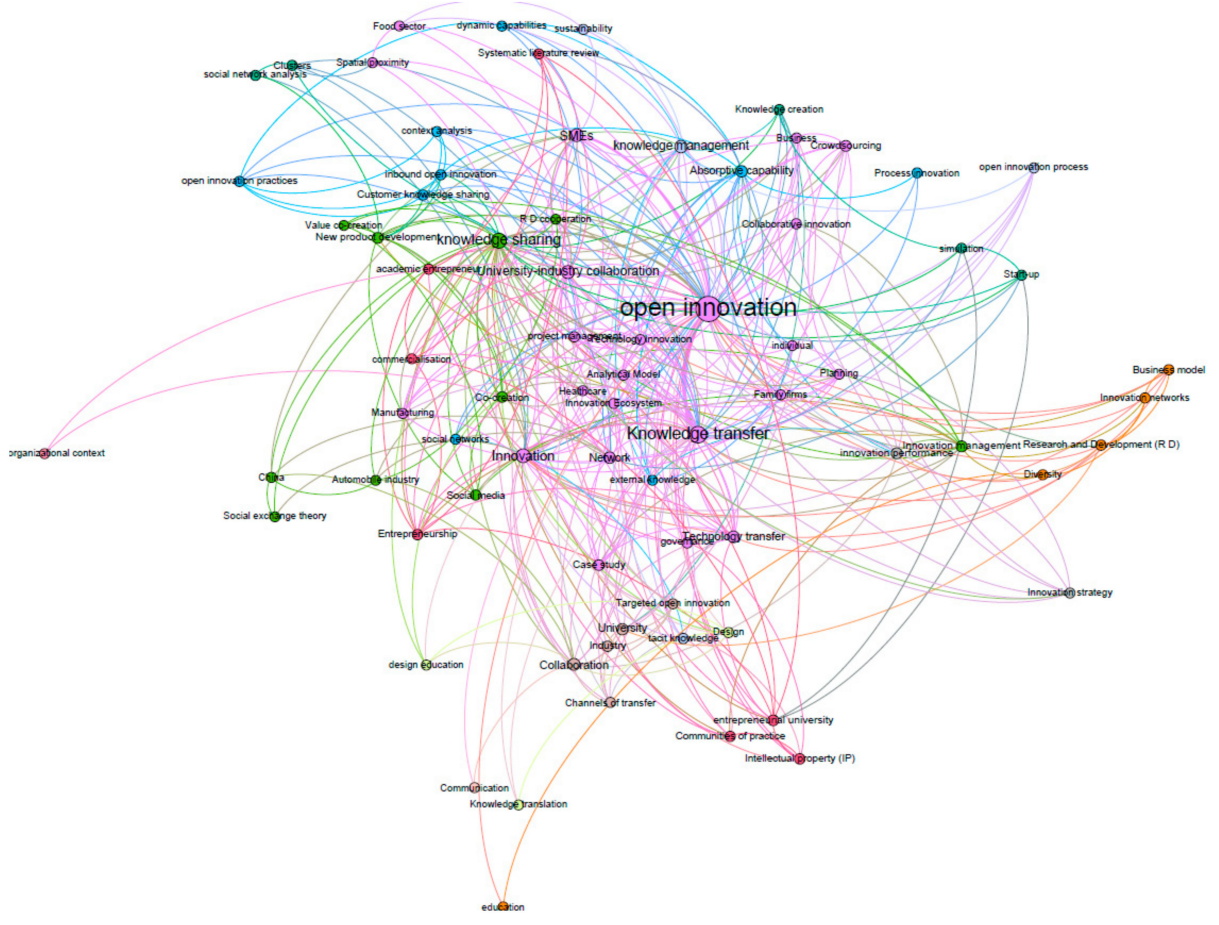

Figure 9. Author's keyword co-occurrence networks: clustering by modularity. 
In order to quantify the co-occurrences of author keywords, their weighted degree is described in Table 7. The weighted degree is represented by the size of the node, and describes the number of links that the author keyword has with other terms. Therefore, a high value indicates that the research topics are closely related to other topics, and will be important reference nodes for future research.

Table 7. Author's keywords ranked by weighted degree.

\begin{tabular}{|c|c|c|c|c|c|}
\hline Ranked & Keywords & $\begin{array}{l}\text { Weighted } \\
\text { Degree }\end{array}$ & Ranked & Keywords & $\begin{array}{l}\text { Weighted } \\
\text { Degree }\end{array}$ \\
\hline 1 & Open Innovation & 453.0 & 16 & Crowdsourcing & 35.0 \\
\hline 2 & Knowledge transfer & 203.0 & 17 & $\begin{array}{l}\text { Entrepreneurial } \\
\text { university }\end{array}$ & 34.0 \\
\hline 3 & Knowledge sharing & 155.0 & 18 & Co-creation & 31.0 \\
\hline 4 & Innovation & 120.0 & 19 & Case study & 30.0 \\
\hline 5 & $\begin{array}{l}\text { University-industry } \\
\text { collaboration }\end{array}$ & 96.0 & 20 & $\begin{array}{l}\text { Intellectual property } \\
\text { (IP) }\end{array}$ & 27.0 \\
\hline 6 & SMEs & 93.0 & 21 & $\begin{array}{c}\text { Research and } \\
\text { Development (R\&D) }\end{array}$ & 25.0 \\
\hline 7 & $\begin{array}{l}\text { knowledge } \\
\text { management }\end{array}$ & 82.0 & 22 & Industry & 24.0 \\
\hline 8 & Collaboration & 66.0 & 23 & Entrepreneurship & 24.0 \\
\hline 9 & Technology transfer & 61.0 & 24 & Tacit knowledge & 22.0 \\
\hline 10 & Network & 54.0 & 25 & $\begin{array}{l}\text { Communities of } \\
\text { practice }\end{array}$ & 21.0 \\
\hline 11 & Absorptive capability & 50.0 & 26 & $\begin{array}{c}\text { Collaborative } \\
\text { innovation }\end{array}$ & 20.0 \\
\hline 12 & University & 49.0 & 27 & Social media & 20.0 \\
\hline 13 & $\begin{array}{l}\text { Innovation } \\
\text { management }\end{array}$ & 41.0 & 28 & Governance & 20.0 \\
\hline 14 & $\begin{array}{l}\text { Innovation } \\
\text { performance }\end{array}$ & 39.0 & 29 & Academic entrepreneur & 19.0 \\
\hline 15 & $\begin{array}{l}\text { New product } \\
\text { development }\end{array}$ & 36.0 & 30 & Clusters & 19.0 \\
\hline
\end{tabular}

In network analysis the most significant basic measures of graphs for predicting emerging research are degree centrality (number of connections), betweenness centrality (bridge nodes) and closeness centrality (closeness to the entire network or influence); in fact, in the study by Shibata et al. [25] the betweenness centrality metric turns out to be the best indicator for predicting the number of future citations of an article as a function of its number of citations. Although no work has been identified that demonstrates this, if we take this study as a similar or referent for the analysis of research topics, the nodes with a high measure of betweenness centrality behave as good intermediaries on other research topics, which makes these nodes research topics of interest for other topics not so related to each other, both now and in the future. In addition, any node of the network presents a high connectivity with other terms (high degree centrality); therefore all the terms have their representativeness within the area of study. However, those terms that have a higher value of betweenness centrality will be considered. Those that play a more important role as a link, therefore, are considered to play an important role in the future. Figure 10 shows the author's keyword co-occurrences network but its nodes have been characterized based on the measure of betweenness centrality, the degree of dark color being the one with the highest measure. It should be noted that in general most of the terms with a higher degree of relationship also have an important role as an intermediary. However, there are several research topics that despite being less collaborative turn out to be good intermediaries, making them more relevant future researchers than others that have a lower degree of betweenness centrality. 


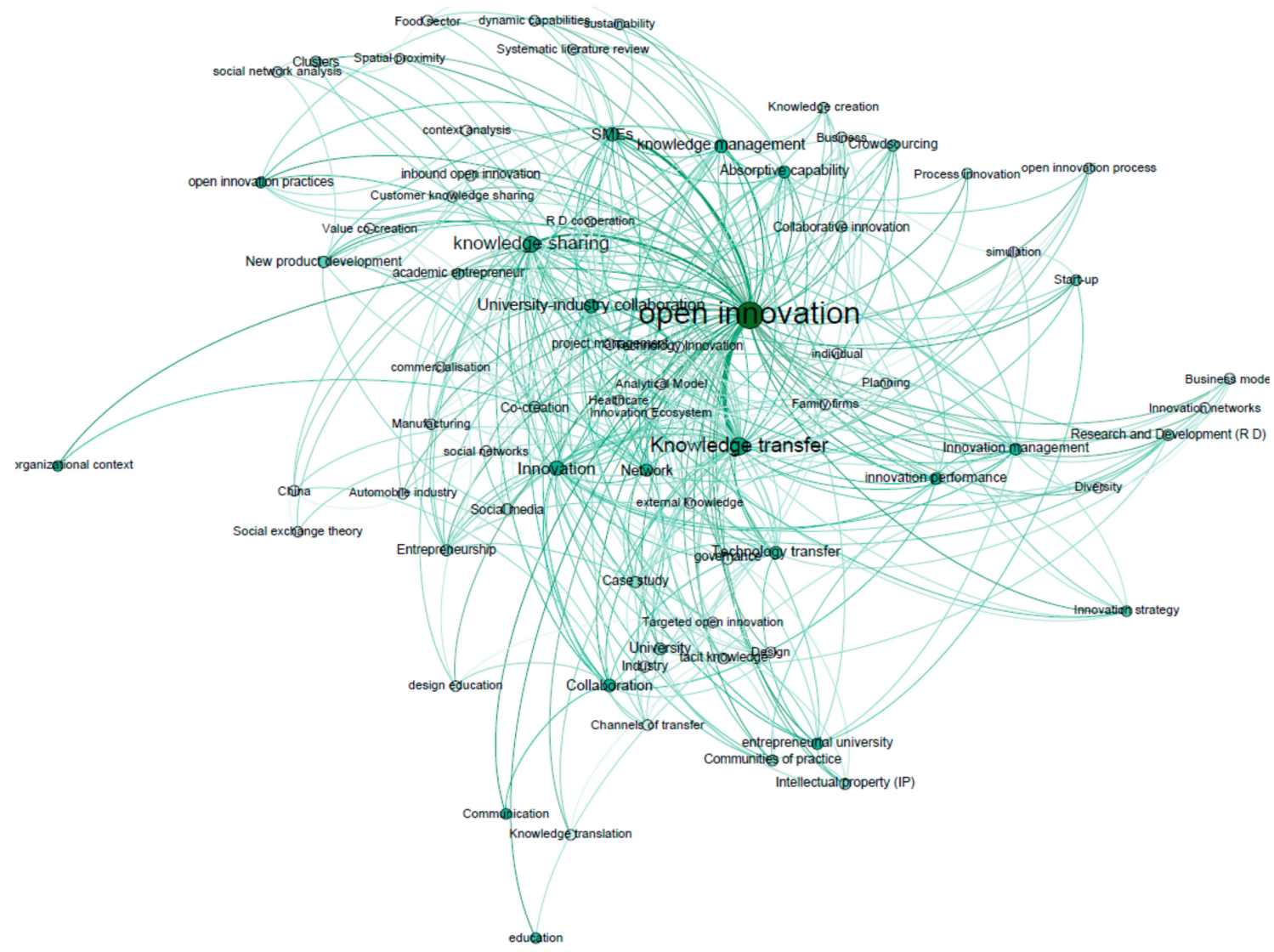

Figure 10. Author's keyword co-occurrence networks: betweenness centrality.

To better evaluate the network, quantification of author's keyword values is represented in Table 8 based on their betweenness centrality measure. Its analysis and comparison with Table 7 allows us to observe that terms such as "Communication", "Inter-organizational context", "Open innovation practices", "education", "Innovation strategy", "Start-up", "Process innovation", "Sustainability" and "Knowledge creation" gain relevance and become important bridge nodes. However, "Tacit knowledge", "Governance" and "Industry" lose relevance, but are still important research topics.

Table 8. Author's keywords ranked by betweenness centrality.

\begin{tabular}{|c|c|c|c|c|c|}
\hline Ranked & Keywords & $\begin{array}{l}\text { Betweenness } \\
\text { Centrality }\end{array}$ & Ranked & Keywords & $\begin{array}{c}\text { Betweenness } \\
\text { Centrality }\end{array}$ \\
\hline 1 & Open innovation & 104.580 & 16 & Open innovation practices & 4011 \\
\hline 2 & Knowledge transfer & 31.700 & 17 & Technology transfer & 3783 \\
\hline 3 & Knowledge sharing & 28.142 & 18 & Education & 3720 \\
\hline 4 & Innovation & 17.602 & 19 & New product development & 3165 \\
\hline 5 & $\begin{array}{l}\text { University-industry } \\
\text { collaboration }\end{array}$ & 17.456 & 20 & Crowdsourcing & 3160 \\
\hline 6 & SMEs & 11.373 & 21 & Innovation strategy & 3105 \\
\hline 7 & Knowledge management & 11.202 & 22 & Start-up & 2894 \\
\hline 8 & Absorptive capability & 7782 & 23 & Clusters & 2686 \\
\hline 9 & Collaboration & 5687 & 24 & University & 2507 \\
\hline 10 & entrepreneurial university & 5604 & 25 & Academic entrepreneur & 2420 \\
\hline 11 & Communication & 5573 & 26 & Case study & 2368 \\
\hline 12 & Network & 4380 & 27 & Communities of practice & 2282 \\
\hline 13 & Innovation performance & 4355 & 28 & $\begin{array}{c}\text { Research and } \\
\text { Development (R D) }\end{array}$ & 2179 \\
\hline 14 & Inter-organizational context & 4333 & 29 & Intellectual property (IP) & 2079 \\
\hline 15 & Innovation management & 4182 & 30 & Co-creation & 2021 \\
\hline
\end{tabular}




\subsection{Where Knowledge Comes from}

The importance of knowing the origin of the most influential knowledge sets in motion the process of identifying the five most cited articles (See Table 9). In addition, according to the results of the study conducted by Shibata et al. [25] the times an article is cited is a good indicator of the times cited in the near future. The results show that the most cited article presents almost four times more citations than the second most cited, which shows that it is a key reference. The article "University-industry relationships and open innovation: Towards a research agenda" thoroughly analyzes the university-business relations and defines a research agenda in an OI context, which makes it highly appreciated as a historical and practical reference to justify a new field of research. European Countries, such as the UK, Italy, Netherlands, Belgium and Finland are leading countries, collaborating with the USA and Russia, and the producing organizations are universities. Among the keywords, the most represented is strategy, so these articles focus their research on something relevant or conclusive to that end. As far as journals are concerned, the most cited journal is 'International Journal Of Management Reviews', one of the top journals in the field of business and management according to the Journal Citation Report 2019. The fourth most frequently cited article is relatively up-to-date from 2017. The next most cited articles are published in journals related to innovation and knowledge management such as the 'Research Policy', 'European Journal of Innovation Management', 'Journal of Knowledge Management' and 'Technovation'. 
Table 9. Where knowledge comes from

\begin{tabular}{|c|c|c|c|c|c|c|c|}
\hline Times Cited & Title & Publication Year & Authors & Affiliations & Country & Source title & Author Keywords \\
\hline 610 & $\begin{array}{l}\text { University-industry relationships } \\
\text { and open innovation: Towards a } \\
\text { research agenda [14] }\end{array}$ & 2007 & $\begin{array}{l}\text { Perkman, M. } \\
\text { Walsh, K. }\end{array}$ & Loughborough Univ & UK & $\begin{array}{l}\text { International } \\
\text { Journal of } \\
\text { Management } \\
\text { Reviews }\end{array}$ & $\begin{array}{l}\text { Strategic research } \\
\text { partnership } \\
\text { Technology-transfer } \\
\text { Academic research }\end{array}$ \\
\hline 175 & $\begin{array}{l}\text { Closed or open innovation? } \\
\text { Problem solving and the } \\
\text { governance choice [58] }\end{array}$ & 2014 & $\begin{array}{c}\text { Felin, } \mathrm{T} \text {. } \\
\text { Zenger, T. }\end{array}$ & $\begin{array}{c}\text { Univ Oxford } \\
\text { Washington Univ }\end{array}$ & $\begin{array}{l}\text { UK } \\
\text { USA }\end{array}$ & Research Policy & $\begin{array}{l}\text { Strategy } \\
\text { Governance choice } \\
\text { Open and closed } \\
\text { innovation }\end{array}$ \\
\hline 121 & $\begin{array}{l}\text { Technological Activities and Their } \\
\text { Impact on the Financial } \\
\text { Performance of the Firm: } \\
\text { Exploitation and Exploration } \\
\text { within and between Firms [59] }\end{array}$ & 2010 & $\begin{array}{l}\text { Belderbos, R. } \\
\text { Faems, D. } \\
\text { Leten, B. } \\
\text { Van Looy, B. }\end{array}$ & $\begin{array}{c}\text { Maastricht Univ } \\
\text { Katholieke Univ Leuven } \\
\text { Univ Twente } \\
\text { Vlerick Leuven Gent } \\
\text { Management Sch } \\
\end{array}$ & $\begin{array}{l}\text { Netherlands } \\
\text { Belgium } \\
\text { Netherlands } \\
\text { Belgium }\end{array}$ & $\begin{array}{l}\text { Journal of Product } \\
\text { Innovation } \\
\text { Management }\end{array}$ & $\begin{array}{l}\text { Strategic alliances } \\
\text { Interorganizational } \\
\text { collaboration } \\
\text { Knowledge transfer }\end{array}$ \\
\hline 110 & $\begin{array}{l}\text { How MNC's subsidiaries may } \\
\text { improve their innovative } \\
\text { performance? The role of external } \\
\text { sources and knowledge } \\
\text { management capabilities [60] }\end{array}$ & 2017 & $\begin{array}{l}\text { Ferraris, A. } \\
\text { Santoro, G. } \\
\text { Dezi, L. }\end{array}$ & $\begin{array}{c}\text { Univ Turin } \\
\text { Ural Fed Univ } \\
\text { Univ Napoli Parthenope }\end{array}$ & $\begin{array}{l}\text { Italy } \\
\text { Russia }\end{array}$ & $\begin{array}{c}\text { Journal of } \\
\text { Knowledge } \\
\text { Management }\end{array}$ & $\begin{array}{c}\text { Open innovation } \\
\text { Innovative performance } \\
\text { External R\&D } \\
\text { Knowledge } \\
\text { management } \\
\end{array}$ \\
\hline 89 & $\begin{array}{l}\text { The Janus face of the } \\
\text { appropriability regime in the } \\
\text { protection of innovations: } \\
\text { Theoretical re-appraisal and } \\
\text { empirical analysis [61] }\end{array}$ & 2007 & $\begin{array}{l}\text { Hurmelinna, P. } \\
\text { Kylaeheiko, K. } \\
\text { Jauhiainen, T. }\end{array}$ & Lappeenranta Univ Technol & Finland & Technovation & $\begin{array}{l}\text { Open innovation } \\
\text { Tacit knowledge } \\
\text { Appropriability regime } \\
\text { Intellectual property }\end{array}$ \\
\hline
\end{tabular}




\section{Discussion}

Scientific production related to the relation between OI concept and knowledge transfer or knowledge sharing has grown slowly over the last 10 years. However, the citation of these scientific documents has grown more. This increase in frequency of citations is a good indicator of the quality of the publications [62] and, at the same time, an important exponent or indicator of dissemination of the research.

Moreover, the most influential publications that should be regarded as important transporters of knowledge are detected by a citation analysis [63]. In addition, the times a publication is cited is a good indicator of its value in the near future [25]. In this case, the most cited publication discussions on university-industry relationships and OI, defining a research agenda, published in 'International Journal of Management Reviews' and developed by Perkman and Walsh from Loughborough University (UK). It becomes a key article, both as a historical reference and as a justification for future scientific actions based on the established research agenda. The main sources of knowledge originate in Europe and from universities, and it should be noted that three of them are international collaborative works between two countries, UK with USA, Belgium with Netherlands and Italy with Russia. As far as the conceptual approach is concerned, the most acclaimed keyword, being the most cited, is 'strategy', which indicates the focus of this research and where it is conceptually oriented.

Regarding the research producers, the UK is the leading University-supported country (Exeter University, Queen's University Belfast, among others), followed by Italy, Romania and Spain. According to the collaboration network, European countries hold the central positions in cooperation, perhaps due to the research funding promoted by the European Union, which has led to an increase in research collaboration between member countries [64]. In addition, the development of information technologies and increased mobility of researchers has made it possible to increase international cooperation. According to [65] "the fourth age of research" has led to the definition of international collaboration as key for organizations. The scientific collaboration network among countries has a core-periphery structure formed by Main European countries (UK, France, Germany and Italy) and the USA, emphasizing that the USA and UK are the countries with a stronger role as intermediaries and influencers on other countries, and highlighting Switzerland as a country that has low production but a serious attitude towards collaboration. Nevertheless, OI paradigm is one of the reasons for international scientific collaboration, as an important way to attract external knowledge and improve the scientific level of the country $[66,67]$.

The most active organizations are from the UK, most notably the University of Exeter, whose results, led mainly by A.T. Alexander, forming a research group with K. Miller and R. McAdam (both from Queens University of Belfast), collaborate in the development of research work with an impact on the scientific community. In general, research is carried out in small, isolated research groups (i.e., they do not collaborate with each other). The most prominent author in terms of his role as an intermediary is Alberto Di Minin, whose collaborative environment is the most extensive, however, the impact of his results is not high. Therefore, in this case the author's collaborative attitude cannot be linked to a direct positive relationship with the impact of his work on the scientific community or that the work becomes the basis of future research. European universities are the most active, but in terms of collaboration the University of Adelaide (Australia) and the National Research University (Russia) are at the top. Even so, the University of Turin has a relevant role in terms of collaboration, emphasizing its capacity to intermediate and influence other organizations. However, Copenhagen Business School and University of Birmingham are two important bridge nodes of collaboration.

The main sources do not differ much in terms of number of publications, and they are linked to the research area of Management and Innovation. However, in terms of impact, the publications of journals located in higher quartiles have greater impact, whereas documents from Conference Proceedings have hardly any impact. According to the relation between journal impact factor and publication citation, results indicate a positive correlation. Consequently, the high quality of the main sources of diffusion infers publications of good scientific quality. 
The level of maturity of a technology could be estimated using a growth curve method [67]. In this case, the extraction of the new terms by year allows the maturity level of the curve to be analyzed, concluding that research into the relationship between OI and knowledge transfer and knowledge sharing concept has been growing since 2010. The network is focused around the term 'Open Innovation', establishing a research environment that brings together terms with more weight by way of collaboration and in terms of their behavior as intermediary nodes, such as 'Knowledge transfer', 'SMEs', 'University-Industry collaboration' and 'Innovation'. The other term of interest for the 'Knowledge sharing' study is grouped with a scientific environment that studies 'Co-creation', 'R\&D cooperation', 'New product development' and, curiously, an 'Automobile industry' sector. These nodes will define a near future in terms of research paths related to knowledge transfer in OI context. The study also shows that new research nodes, less conventional than previous ones, are opening the way to become study references, such as 'Communication', 'Inter-organizational context', 'Open innovation practices', 'Education', 'Innovation strategy, 'Start-up', 'Process innovation', 'Sustainability' and 'Knowledge creation'.

\section{Conclusions}

Knowledge management is exploring new fields of action due to the current dynamic context and the need to search for new innovative paths in industry, such as OI models. Therefore, the bibliometric and network analysis provides a picture of the trajectory followed by science, identifying the geographical location of research, producers and their collaborative networks, research priorities, which will help researchers and their environment both to locate working groups and forecast new research items, as well as to assist in decision making. Europe stands out as the main continent in research into OI linked to knowledge transfer, and its research teams are small and isolated, usually belonging to the same organization. Despite the fact that its scientific production has been constant over the last ten years, there has been an important generation of new study topics related to this field of research. Therefore, it can be concluded that research is still active and evolving. It is very important for the scientific community to know both the current state of evolution and what the most researched fields of research are. This will allow them to better focus their future research, as well as to identify the foremost sources of knowledge as the main sources of publication. Among the identified fields of research, two that differ from the subject of study stand out: university-industry collaboration and SMEs. Future research frameworks related to these items and others identified as key for the near future may be proposed, providing the scientific community with research guidelines. Considering the importance of R\&D collaborations (closely related to both university-industry collaboration) in an OI context, it would be interesting to analyze the networks for knowledge sharing that are formed and the influence they have on industrial performance and technological development in order to justify the strategic importance of an organizational approach based on an OI perspective. To this end, we could study the behavior of scientific, technological and social networks within a specific organization.

Author Contributions: Conceptualization, I.A.-M. and N.P.-G.; methodology, I.A.-M.; software, I.A.-M. and N.P.-G.; validation, I.A.-M., N.P.-G. and R.M.R.-B.; formal analysis, I.A.-M. and N.P.-G.; investigation, I.A.-M. and N.P.-G.; resources, I.A.-M.; data curation, N.P.-G.; writing-original draft preparation, I.A.-M. and N.P.-G.; writing-review and editing I.A.-M., N.P.-G. and R.M.R.-B.; visualization, I.A.-M.; supervision, R.M.R.-B. All authors have read and agreed to the published version of the manuscript.

Funding: This research received no external funding.

Conflicts of Interest: The authors declare no conflict of interest.

\section{References}

1. Smart, P.; Holmes, S.; Lettice, F.; Pitts, F.H.; Zwiegelaar, J.B.; Schwartz, G.; Evans, S. Open Science and Open Innovation in a socio-political context: Knowledge production for societal impact in an age of post-truth populism. R D Manag. 2019, 49, 279-297. [CrossRef] 
2. Hoffmann, V.H.; Probst, K.; Christinck, A. Farmers and researchers: How can collaborative advantages be created in participatory research and technology development? Agric. Hum. Values 2007, 24, 355-368. [CrossRef]

3. Meissner, D.; Shmatko, N. Integrating professional and academic knowledge: The link between researchers skills and innovation culture. J. Technol. Transf. 2019, 44, 1273-1289. [CrossRef]

4. Chesbrough, H. Managing Open Innovation. Res. Manag. 2004, 47, 23-26. [CrossRef]

5. Anderson, A.R.; Hardwick, J. Collaborating for innovation: The socialised management of knowledge. Int. Entrep. Manag. J. 2017, 13, 1181-1197. [CrossRef]

6. Vanhaverbeke, W. Open Innovation: Researching a New Paradigm:The inter-organizational context of open innovation. In October; Chesbrough, H., Vanhaverbeke, W., West, J., Eds.; Oxford University Press: Boston, MA, USA, 2006; pp. 205-219.

7. Crossan, M.M. The Knowledge-Creating Company: How Japanese Companies Create the Dynamics of Innovation. J. Int. Bus. Stud. 1996, 27, 196-201. [CrossRef]

8. Liu, L.L.; Du, R.; Ai, S.Z. Impact of Culture on the Relationship between Knowledge Sharing and Innovative Behavior in IT Services Industry. Chin. J. Manag. Sci. 2016, 24, 159-166.

9. Tu, X.Y.; Wang, Z.Y.; He, X.; Zhang, Q. Critical Thinking, Creative Process Engagement and Innovation Behavior: The Empirical Study of Technology-Based Enterprises; CNKI: Beijing, China, 2018; Volume 36, pp. 1-10.

10. Pian, Q.Y.; Jin, H.; Li, H. Linking knowledge sharing to innovative behavior: The moderating role of collectivism. J. Knowl. Manag. 2019, 23, 1652-1672. [CrossRef]

11. Ritala, P.; Olander, H.; Michailova, S.; Husted, K. Knowledge sharing, knowledge leaking and relative innovation performance: An empirical study. Technovation 2015, 35, 22-31. [CrossRef]

12. Du Plessis, M. The role of knowledge management in innovation. J. Knowl. Manag. 2007, 11, 20-29. [CrossRef]

13. Becker, B.A.; Eube, C. Open innovation concept: Integrating universities and business in digital age. J. Open Innov. Technol. Mark. Complex. 2018, 4, 12-16. [CrossRef]

14. Perkmann, M.; Walsh, K. University-industry relationships and open innovation: Towards a research agenda. Int. J. Manag. Rev. 2007, 9, 259-280. [CrossRef]

15. Žemaitis, E. Knowledge Management in Open Innovation Paradigm Context: High Tech Sector Perspective. Procedia Soc. Behav. Sci. 2014, 110, 164-173. [CrossRef]

16. Van Nunen, K.; Li, J.; Reniers, G.; Ponnet, K. Bibliometric analysis of safety culture research. Saf. Sci. 2018, 108, 248-258. [CrossRef]

17. Wang, B.; Pan, S.-Y.; Ke, R.-Y.; Wang, K.; Wei, Y.-M. An overview of climate change vulnerability: A bibliometric analysis based on Web of Science database. Nat. Hazards 2014, 74, 1649-1666. [CrossRef]

18. Ospina-Mateus, H.; Jiménez, L.A.Q.; Lopez-Valdes, F.J.; Salas-Navarro, K. Bibliometric analysis in motorcycle accident research: A global overview. Scientometrics 2019, 121, 793-815. [CrossRef]

19. Ugolini, D.; Bonassi, S.; Cristaudo, A.; Leoncini, G.; Ratto, G.B.; Neri, M. Temporal trend, geographic distribution, and publication quality in asbestos research. Environ. Sci. Pollut. Res. 2014, 22, 6957-6967. [CrossRef]

20. Cobo, M.J.; López-Herrera, A.G.; Herrera-Viedma, E.; Herrera, F. Science mapping software tools: Review, analysis, and cooperative study among tools. J. Am. Soc. Inf. Sci. Technol. 2011, 62, 1382-1402. [CrossRef]

21. Börner, K.; Chen, C.; Boyack, K.W. Visualizing knowledge domains. Annu. Rev. Inf. Sci. Technol. 2005, 37, 179-255. [CrossRef]

22. Van Eck, N.J.; Waltman, L.; Dekker, R.; Berg, J.V.D. A comparison of two techniques for bibliometric mapping: Multidimensional scaling and VOS. J. Am. Soc. Inf. Sci. Technol. 2010, 61, 2405-2416. [CrossRef]

23. De Paulo, A.F.; Porto, G.S. Solar energy technologies and open innovation: A study based on bibliometric and social network analysis. Energy Policy 2017, 108, 228-238. [CrossRef]

24. Li, W.; Zhao, Y. Bibliometric analysis of global environmental assessment research in a 20-year period. Environ. Impact Assess. Rev. 2015, 50, 158-166. [CrossRef]

25. Shibata, N.; Kajikawa, Y.; Matsushima, K. Topological analysis of citation networks to discover the future core articles. J. Am. Soc. Inf. Sci. Technol. 2007, 58, 872-882. [CrossRef]

26. Maharani, W. Identifying influential user in twitter: Analysis of tweet content similarity in weighted network. J. Theor. Appl. Inf. Technol. 2015, 81, 558-563.

27. Randhawa, K.; Wilden, R.; Hohberger, J. A Bibliometric Review of Open Innovation: Setting a Research Agenda. J. Prod. Innov. Manag. 2016, 33, 750-772. [CrossRef] 
28. Gao, H.; Ding, X.-H.; Wu, S. Exploring the domain of open innovation: Bibliometric and content analyses. J. Clean. Prod. 2020, 275, 122580. [CrossRef]

29. Kovács, A.; Van Looy, B.; Cassiman, B. Exploring the scope of open innovation: A bibliometric review of a decade of research. Scientometrics 2015, 104, 951-983. [CrossRef]

30. De Paulo, A.F.; Carvalho, L.C.; Costa, M.T.G.; Lopes, J.E.F.; Galina, S.V. Mapping Open Innovation: A Bibliometric Review to Compare Developed and Emerging Countries. Glob. Bus. Rev. 2017, 18, 291-307. [CrossRef]

31. Ebrahim, N.A.; Bong, Y.B. Open Innovation: A Bibliometric Study. Int. J. Innov. 2017, 5, 411-420. [CrossRef]

32. Lopes, A.P.V.B.V.; De Carvalho, M.M. Evolution of the open innovation paradigm: Towards a contingent conceptual model. Technol. Forecast. Soc. Chang. 2018, 132, 284-298. [CrossRef]

33. Le, H.T.T.; Dao, Q.T.M.; Pham, V.-C.; Tran, D.T. Global trend of open innovation research: A bibliometric analysis. Cogent Bus. Manag. 2019, 6, 1633808. [CrossRef]

34. Aziz, E.; Mustapha, H.; Jamila, E.A. A bibliometric study of the recent advances in open innovation concept. Procedia Comput. Sci. 2020, 175, 683-688. [CrossRef]

35. Odriozola-Fernández, I.; Berbegal-Mirabent, J.; Merigó, J.M. Open innovation in small and medium enterprises: A bibliometric analysis. J. Organ. Chang. Manag. 2019, 32, 533-557. [CrossRef]

36. Noviaristanti, S. Understanding Open Innovation in Large Firms: A Co-citation Bibliometric Analysis. In Proceedings of the 2nd Padang International Conference on Education, Economics, Business and Accounting (PICEEBA-2 2018); Dwita, V., Handayani, D.F., Sari, Y.P., Sari, A.Y., Yeni, I., Eds.; Atlantis Press: Paris, France, 2019; Volume 64, pp. 448-455, ISBN 978-94-6252-703-4.

37. Seguí-Mas, E.; Signes-Pérez, E.; Sarrión-Viñes, F.; Vidal, J.A. Bibliometric analysis of the international literature on open innovation and absorptive capacity. Intang. Cap. 2016, 12, 51-72. [CrossRef]

38. Della Corte, V.; Del Gaudio, G.; Sepe, F.; Sciarelli, F. Sustainable Tourism in the Open Innovation Realm: A Bibliometric Analysis. Sustainability 2019, 11, 6114. [CrossRef]

39. Naushad, A.P.M.; Malik, B.A.; Raza, A. Bibliometric analysis of literature on knowledge sharing. Annals. Libr. Inf. Stud. 2018, 65, 217-227.

40. Skute, I. Opening the black box of academic entrepreneurship: A bibliometric analysis. Scientometrics 2019, 120, 237-265. [CrossRef]

41. Kokol, P.; Žlahtič, B.; Žlahtič, G.; Zorman, M.; Podgorelec, V. Knowledge Management in Organizations-A Bibliometric Analysis of Research Trends. Lect. Notes Bus. Inf. Process. 2015, 224, 3-14. [CrossRef]

42. Aman, V. A new bibliometric approach to measure knowledge transfer of internationally mobile scientists. Scientometrics 2018, 117, 227-247. [CrossRef]

43. Apriliyanti, I.D.; Alon, I. Bibliometric analysis of absorptive capacity. Int. Bus. Rev. 2017, 26, 896-907. [CrossRef]

44. Agostini, L.; Nosella, A.; Sarala, R.; Spender, J.-C.; Wegner, D. Tracing the evolution of the literature on knowledge management in inter-organizational contexts: A bibliometric analysis. J. Knowl. Manag. 2020, 24, 463-490. [CrossRef]

45. Appleyard, M.M.; Chesbrough, H.W. The Dynamics of Open Strategy: From Adoption to Reversion. Long Range Plan. 2017, 50, 310-321. [CrossRef]

46. Carvalho, M.; Fleury, A.; Lopes, A.P. An overview of the literature on technology roadmapping (TRM): Contributions and trends. Technol. Forecast. Soc. Chang. 2013, 80, 1418-1437. [CrossRef]

47. Meho, L.I.; Yang, K. Impact of data sources on citation counts and rankings of LIS faculty: Web of science versus scopus and google scholar. J. Am. Soc. Inf. Sci. Technol. 2007, 58, 2105-2125. [CrossRef]

48. Xu, L.; Marinova, D. Resilience thinking: A bibliometric analysis of socio-ecological research. Scientometrics 2013, 96, 911-927. [CrossRef]

49. Martín-Martín, A.; Orduña-Malea, E.; Thelwall, M.; Delgado-López-Cózar, E. Google Scholar, Web of Science, and Scopus: A systematic comparison of citations in 252 subject categories. J. Inf. 2018, 12, 1160-1177. [CrossRef]

50. Arora, S.K.; Porter, A.L.; Youtie, J.; Shapira, P. Capturing new developments in an emerging technology: An updated search strategy for identifying nanotechnology research outputs. Scientometrics 2012, 95, 351-370. [CrossRef]

51. Buckland, M.; Gey, F. The relationship between Recall and Precision. J. Am. Soc. Inf. Sci. 2018, 45, 12-19. [CrossRef] 
52. Chesbrough, H.W. Open Innovation: The New Imperative for Creating and Profiting from Technology; Harvard Business School Press: Boston, MA, USA, 2003.

53. Search Technology the Vantage Point. Available online: https://www.thevantagepoint.com/ (accessed on 15 July 2020).

54. Bastian, M.; Heymann, S.; Jacomy, M. Gephi: An open source software for exploring and manipulating networks. In Proceedings of the International AAAI Conference on Weblogs and Social Media; The AAAI Press: Menlo Park, CA, USA, 2009; pp. 361-362.

55. Gui, Q.; Liu, C.; Du, D. Globalization of science and international scientific collaboration: A network perspective. Geoforum 2019, 105, 1-12. [CrossRef]

56. Barrios, C.; Flores, E.; Martínez, M.Á.; Ruiz-Martínez, M. Is there convergence in international research collaboration? An exploration at the country level in the basic and applied science fields. Scientometrics 2019, 120, 631-659. [CrossRef]

57. Clarivate Analytics Research Area Schemes. Available online: http://help.prod-incites.com/inCites2Live/ filterValuesGroup/researchAreaSchema.html (accessed on 13 November 2020).

58. Felin, T.; Zenger, T.R. Closed or open innovation? Problem solving and the governance choice. Res. Policy 2014, 43, 914-925. [CrossRef]

59. Belderbos, R.; Faems, D.; Leten, B.; Van Looy, B. Technological Activities and Their Impact on the Financial Performance of the Firm: Exploitation and Exploration within and between Firms*. J. Prod. Innov. Manag. 2010, 27, 869-882. [CrossRef]

60. Ferraris, A.; Santoro, G.; Dezi, L. How MNC's subsidiaries may improve their innovative performance? The role of external sources and knowledge management capabilities. J. Knowl. Manag. 2017, 21, 540-552. [CrossRef]

61. Hurmelinna, P.; Kyläheiko, K.; Jauhiainen, T. The Janus face of the appropriability regime in the protection of innovations: Theoretical re-appraisal and empirical analysis. Technovation 2007, 27, 133-144. [CrossRef]

62. Moed, H.F. Citation Analysis in Research Evaluation; Springer: Berlin/Heidelberg, Germany, 2005; ISBN 9781402037146.

63. Liñán, F.; Fayolle, A. A systematic literature review on entrepreneurial intentions: Citation, thematic analyses, and research agenda. Int. Entrep. Manag. J. 2015, 11, 907-933. [CrossRef]

64. Ferligoj, A.; Kronegger, L.; Mali, F.; Snijders, T.A.B.; Doreian, P. Scientific collaboration dynamics in a national scientific system. Scientometrics 2015, 104, 985-1012. [CrossRef]

65. Adams, J. The fourth age of research. Nat. Cell Biol. 2013, 497, 557-560. [CrossRef]

66. Gui, Q.; Liu, C.; Du, D. The Structure and Dynamic of Scientific Collaboration Network among Countries along the Belt and Road. Sustainability 2019, 11, 5187. [CrossRef]

67. Roper, A.T.; Cunningham, S.W.; Porter, A.L.; Mason, T.W.; Rossini, F.A.; Banks, J. Forecasting and Management of Technology; John Wiley \& Sons: Hoboken, NJ, USA, 2011; ISBN 9780470440902.

Publisher's Note: MDPI stays neutral with regard to jurisdictional claims in published maps and institutional affiliations.

(C) 2020 by the authors. Licensee MDPI, Basel, Switzerland. This article is an open access article distributed under the terms and conditions of the Creative Commons Attribution (CC BY) license (http://creativecommons.org/licenses/by/4.0/). 